\title{
13. Entertaining children: The 1927 Royal Commission on the Motion Picture Industry as a site of women's leadership
}

\author{
Mary Tomsic ${ }^{1}$
}

What I object to is the exploitation of our children. I know what the exploitation of natives is, because I have lived among them, and we certainly object to it. I am very sorrowful that we in Australia are willing to exploit our children from a financial aspect or even for our own pleasure.

\section{— Mrs John Jones}

Mrs John Jones, president of the Victorian Women's Citizen Movement, presented the above evidence to the Royal Commission on the Moving Picture Industry in Australia in $1927 .{ }^{2}$ Jones compared the exploited children with exploited 'natives' - both presumably requiring protection in the form of benevolent control. And it was a particular type and class of woman who could provide such control and guidance. For the women reformers, and also men, who appeared before the commission, the cinema was understood as a public arena in which a novel visual language was spoken. The relative accessibility of the cinema to all classes of people concerned women reformers, and the effects of motion pictures on children were scrutinised in much detail. These women reformers saw a place for themselves in the regulation of film viewing. It was a way in which a 'natural' maternal role, usually private, was made public; they acted as the 'responsible' mothers for the nation's children.

In this collection Amanda Sinclair proposes that we should think about leadership as 'a process of influence', which often aims at 'mobilising people towards change'. Sinclair asks us to consider how women have 'influenced and changed the public agenda and improved the life experience of the people around and following after them'. This definition and question provide a valuable framework to apply to the public activities of women who campaigned

\footnotetext{
1 The University of Melbourne.

2 Mrs John Jones, in Commonwealth of Australia, Royal Commission on the Moving Picture Industry in Australia, Minutes of Evidence (Canberra: Commonwealth of Australia, 1927), para. 3328, 107 [hereinafter evidence from this transcript is cited as $R C E$ ]. This was submitted evidence presented to the Select Committee on 2 May 1927 that was also submitted to the royal commission.
} 
to regulate film viewing for children during the late 1920s in Australia. Women reformers who presented evidence at the royal commission were keen to see changes in the public agenda, specifically in how film-going was regulated for children, how systems of classification could operate and what was suitable screen entertainment for children. From a contemporary perspective, it is easy to question precisely the nature of some of the 'improvements', and it is important that we interrogate the ideologies of social class, gender and race embodied in many of their ideas. But in doing this, there is also value in considering the actions and evidence of these women to more fully interrogate the basis on which they made their claims. I would like to suggest that in considering how these women presented their authority of speaking and providing evidence, we can see these women explaining and justifying their gendered form of cultural leadership. Examining these particular women's cultural activism provides evidence of a historical case of women's leadership.

In this chapter I want to examine the evidence of women advocating for children's screen entertainment as examples of leadership, and importantly, consider how this leadership was given currency and authority by invoking the ideology of maternal citizenship. An important element of this is the nature of the way the relationship between women and children is understood and enacted. I will discuss this relationship briefly before looking specifically at the evidence of women reformers. Doing this provides insights into how leadership was enacted by particular women and how they asserted influence in society to mobilise change.

\section{Maternal citizenship}

The work of women advocating for children's screen entertainment can be firmly placed in the realm of maternal citizenship. In writing about feminist interpretations of citizenship - in particular, women's relationship with the state - Marilyn Lake suggests that citizens' individual rights were conceptualised in radical ways 'without neglecting citizens' collective responsibilities'. ${ }^{3}$ Lake identifies 'the mother' as strategically critical in linking rights with responsibilities in the discourse on maternal citizenship: 'Central ... was the insistence on the duty of citizens to protect and care for the more vulnerable, helpless members of the community-hence the campaigns for temperance, censorship of films and books, raising the age of consent, and the state provision of infant and maternal welfare. ${ }^{4}$

3 Marilyn Lake, 'Feminist Creating Citizens', in Creating Australia: Changing Australian History, eds Wayne Hudson and Geoffrey Bolton (Sydney: Allen \& Unwin, 1997), 104.

4 Ibid. 
In addition to this, structurally children in democracies are in an interesting position, as their access to direct political, social and economic citizenship is limited. Theoretically there is considerable difference between guardianship and democracy, ${ }^{5}$ but in practice, children require advocates. ${ }^{6}$ While both women and men interested in social work and children engaged in public discussions about suitable entertainment for children, often women's presence was linked to the guardianship of children. Either implicitly or explicitly, the category of mother plays a central role in discussions of suitable children's screen entertainment, and has been effectively mobilised by women activists. But as will be shown, this was not necessarily a straightforward invocation of the 'mother'; some detailed attention was paid to the necessary qualifications a woman censor would require. What was not questioned, however, was children's recreation as a civic entitlement. The implied prerogative to leisure and recreation has featured historically in the Australian context. For instance, amusements are included in Justice Higgins' list of items of expenditure he considered suitable for a 'human being living in a civilized community' and in a condition of 'frugal comfort estimated by current human standards' in his Harvester Judgment of 1907. ${ }^{7}$ In this way, participating in entertainment is presented as part of being a member of a 'civilised' community. While this right to leisure has been understood in practice as a masculine one, ${ }^{8}$ particularly as it played out in discussions about wages and maternal payment allowances, in the context of film-going in the late 1920s, entertainment was taken as granted as appropriate for (female and male) children. While women's advocacy should be understood as part of a project of enacting maternal citizenship and leadership, it could also be understood as contributing to children's social citizenship, albeit with a highly moralistic basis.

\section{Women's role in film censorship}

There had been federal film censorship in Australia since 1917, and by 1927 there were (or had been) censorship boards in New South Wales, South Australia and Tasmania. Victoria had made an agreement with the federal authority for

\footnotetext{
5 Francis Schrag, 'Children and Democracy: Theory and Policy', Politics, Philosophy \& Economics 3(3) (October 2004): 365-6.

6 Schrag discusses ways in which children who are excluded from participation in democracies can be included, with suggestions including a parental vote or appointment of a children's guardian; in ibid.

7 Harvester Case, Ex parte HV McKay, 1907, 4 (Canberra: Parliament of Australia, Parliamentary Library), http://www.aph.gov.au/binaries/library/intguide/law/harvester.pdf.

8 Or even as a (male) citizen's duty. See Lake, 'Feminists Creating Citizens', 101; also Marilyn Lake, 'A Revolution in the Family; the Challenge and Contradictions of Maternal Citizenship in Australia', in Mothers of a New World: Maternalist Politics and the Origins of Welfare States, eds Seth Koven and Sonya Michel (New York: Routledge, 1993), 391.
} 
it to censor films on Victoria's behalf. ${ }^{9}$ All other States maintained the right to independent State censorship. The NSW board was established in the early 1900s and comprised five government officials. ${ }^{10}$ South Australia appointed an advisory board of film censors in 1917 to assist the chief secretary in judging films. ${ }^{11}$ While there had been pressure to create a State film censorship authority in Tasmania from 1916, it was not until the Federation of Women's Societies for Film Censorship met publicly to lobby for this that regulations were made to appoint local censors. ${ }^{12}$ In March 1918 a board of five members, including two women, Edith Waterworth and Mary Taylor, was appointed. ${ }^{13}$ Although all the State boards were not in continual operation, they tended to be reactive, responding to current moving pictures being shown or 'offensive' posters displayed. The boards were no longer operating at the beginning of World War II. ${ }^{14}$

Professor Robert Wallace was the chief censor of motion pictures from 1922 to 1927. ${ }^{15}$ Wallace, also Professor of English and Literature at the University of Melbourne, was based in Melbourne while the majority of films were imported into Australia in Sydney. So from 1925, Walter Cresswell O'Reilly was appointed the senior Commonwealth film censor in Sydney and was responsible for essentially all of the censoring. Most of the films he examined were from the United States. In 1927, of the 715 feature films imported into Australia, 674 were from the United States and 25 from the United Kingdom. Seven Australian feature films were produced in the same year. ${ }^{16}$

All of the women witnesses who appeared before the royal commission and on behalf of women's organisations supported the presence of women on the proposed censorship boards (somewhere between 20 and 50 per cent). ${ }^{17}$ Having formal positions on the boards was understood as particularly important for many of the women's organisations. Mrs Jones stated that her organisation,

9 Diane Collins, Hollywood Down Under: Australians at the Movies 1896 to the Present Day (Sydney: Angus \& Robertson, 1987), 54; Commonwealth of Australia, 'Report of the Royal Commission on the Moving Picture Industry in Australia', 1, Commonwealth Parliamentary Papers, Session 1926-27-28, vol. IV, pt 2, para. $37,6$. 10 Ina Bertrand, Film Censorship in Australia (Brisbane: University of Queensland Press, 1978), 41; Commonwealth of Australia, 'Report of the Royal Commission', para. 34, 6.

11 Bertrand, Film Censorship, 56.

12 Ibid., 58.

13 Stefan Petrow, 'Leading Ladies: Women and Film Censorship in Early Twentieth Century Tasmania', Tasmanian Historical Research Association Papers and Proceedings 41(2) (June 1994): 80.

14 New South Wales ceased in 1923, Tasmania in 1934 and South Australia in 1938. See Bertrand, Film Censorship, 59-60.

15 Ursula Bygott, 'Wallace, Sir Robert Strachan (1882-1961)', Australian Dictionary of BiographyOnline (Canberra: National Centre of Biography, The Australian National University, 1990), http://adb.anu.edu.au/ biography/wallace-sir-robert-strachan-8962/text15767.

16 Commonwealth Film Censorship Reports, 1925-1939, in Diane Collins, 'Cinema and Society in Australia 1920-1939' (PhD thesis, Department of History, University of Sydney, 1975), app. A, 461; Andrew Pike and Ross Cooper, Australian Film (Melbourne: Oxford University Press, 1981), 178-84.

17 Waterworth (in $R C E$, para. 16923, 590) said on a board of four, two women were needed, and on a board of two, one woman; Muscio (in $R C E$, para. 21730, 804) said at least two women were needed on a board of 
the Victorian Women's Citizen Movement, wanted to secure 'representation of women in Parliament and in all boards and commissions' as it is the 'only method of getting a higher moral and spiritual tone in the life of Australia' ${ }^{18}$ This defines women as moral guardians. It explicitly demonstrates the approach taken to carve an area of women's influence in the public arena in maternalistic terms. Representatives of women's organisations believed the impact of these roles to be far reaching. Ruby Rich declared that 'women's organizations throughout the Empire are looking to Australia as the most advanced democracy or the political laboratory of the world, to see what we are doing in that direction' ${ }^{19}$

The chief censor, Wallace, supported the presence of a woman on a censorship board. He thought a 'woman as a single censor would be undesirable, because the importers would have difficulty in discussing with her matters which they now discuss with us', but as a member of a board 'that difficulty vanishes' ${ }^{20}$ One witness, Elsie Sleeman Reed, secretary of the Young Women's Christian Association (YWCA) in Brisbane, was asked if the presence of a woman on a board would mean that 'it would be difficult to arrive at an agreement'. Unsurprisingly, she disagreed: 'No, she would give them the woman's point of view. ${ }^{21}$ Wallace was asked if a woman's presence on the board would restrict the discussions men could have about a film. Wallace disagreed overall but included specific conditions: 'I have had to discuss these things with women, and the difficulty need not be stressed, provided the woman is of mature experience, and is, preferably, married. ${ }^{22}$

While women's role in censorship was not focused solely in terms of protecting children, the issue of a woman censor was almost always raised in connection with children. Censorship was widely debated and was a key avenue through which women reformers articulated their desires to influence screen culture and also expressed their beliefs regarding suitable screen material for children.

Ruby Rich was vice-president of the Federated Women's Societies of New South Wales. Organisations included under this umbrella were the Feminist Club of Sydney, the Women's League, the Women's Service League, Women's Christian Temperance Union (WCTU) and the Women's League of Voters. ${ }^{23}$ Parts of her evidence were echoed in that of many other witnesses. Rich, speaking in her

\footnotetext{
five and at least one on a board of three; Morris (in RCE, paras 16089-91, 560), Rich (in RCE, para. 19965, 736) and the Australian Federated Women's Societies of New South Wales proposed that at least one woman should be included on the board.

$18 R C E$, para. $3389,111$.

19 Ibid., paras 19961-4, 736.

20 Ibid., para. 13475, 450.

21 For example, Reed, in ibid., para. 9722, 333.

22 Ibid., para. 13534, 453.

23 Rich reported this organisation was affiliated with the British Commonwealth League and the International Suffrage Alliance. Ibid., para. 19964, 736.
} 
organisational capacity, said that not only is it 'generally conceded that women are the best custodians of the children', but also that '[a] nation is no stronger than the mothers of its people, and we are convinced that with a woman on the censorship board there will be greater protection for the rising generation'.$^{24}$ Despite this, she clearly indicated that children were connected not only to women, but also to men. 'Some men', she said, 'appear not to realize that we want a woman to be there to protect their children as well as ours' ${ }^{25}$

Many witnesses at the royal commission were asked about suitable qualifications for a woman censor. Rich, again explicitly on behalf of the organisations she represented, said they did not seek 'the appointment of a "wowser"', but the 'essential qualifications' for both male and female censors were 'a full knowledge of diversified public feeling and a complete understanding of sex psychology'. These would be held by a person with 'a high standard of education, refinement of thought ... general understanding of the film industry, a knowledge of the movement of the public pulse, the trend of public outlook, and a comprehensive idea of British ideals'.$^{26}$ The commissioners countered this, restating suggestions that appropriate qualifications for a woman should be that she was married, with a family and preferably had travelled 'for the purpose of broadening her mind'. Rich felt these were too restrictive and, should an appointment be made through a women's organisation, an appropriate censor could be found. ${ }^{27}$ It was through women's organisations, like the ones Rich represented, that a broad basis of support was publicly presented for women to be formally involved with federal censorship. So while women representing a range of women's groups and organisations were given the opportunity to appear before the royal commission, it seems apparent from the way commissioners asked questions that their focus was more on individual women's specific skills, rather than leaving this to women's groups to put forward suitable female candidates.

The commissioners questioned whether Rich's criteria for a suitable censor would exclude women who had household duties. Rich replied that she doubted 'if a woman who has confined herself to home duties would have the broad view necessary for the duties of a censor of films' for the women of the Empire who attended motion pictures. ${ }^{28}$ After being asked again, she said she did not see that marriage and family alone were vital qualifications: 'a thorough knowledge of children' was necessary, but the 'maternal instinct does not arise only from the act of giving birth to a child. It may be highly developed in other women and especially in teachers who have much to do with children.' ${ }^{29}$ The issue of

\footnotetext{
24 Ibid., para. 19965, 736.

25 Ibid., emphasis added.

26 Ibid.

27 Ibid., para. 19967, 737.

28 Ibid., para. 19969, 737.

29 Ibid., para. 19970, 737.
} 
travel was also often discussed as a requirement for a woman censor. During this questioning, Rich returned to the domestic sphere. Rich reiterated that domesticity alone did not cultivate the broad range of knowledge she saw as essential for a woman censor's representational requirements: 'The fact that a woman may live a great deal of time in her home does not entitle her to speak on behalf of all the women of Australia.' ${ }^{30}$

Rich presents the case for a woman censor being required as part of claims for equality in citizenship but also because in Australia 'it is estimated that fully one half' of the cinema audience is women and children. ${ }^{31}$ In this way, linking the cultural leadership of women to a guardianship function for women and children reveals a practical understanding of women's citizenship; one effectively founded by a cultivation of maternal knowledge. In contrast with this, Edith Alice Waterworth, a welfare worker who was a member of the Picture Censor Board in Hobart, quite explicitly commented on a dual basis for women's public representation in contrast with a singular claim for men: 'Men have their claim as citizens and electors; we have a claim as electors and citizens, and another as mothers.' 'Nature has given us the work of bearing children' and from this women 'necessarily have to give far more careful thought to the rearing of children than is given by a father'. ${ }^{32}$ While acknowledging women's individual status as citizens, she nonetheless intimately linked their public representation work to childrearing:

If the Federal Government considers that we are not capable of judging what is good for our children, it should, to be consistent, take those children from us as soon as they are born and let men rear them. But if we're allowed to bring them up, we should have some say regarding the influences they have to face when they go into the world. ${ }^{33}$

In this statement, motherhood is presented as the key basis for women's civic value - something denied to Indigenous women, with many of their children taken from them in almost precisely the manner Waterworth (improbably) describes. ${ }^{34}$

Mrs John Jones, president of the Victorian Women Citizen Movement, described who she saw as a suitable woman to be on the board of censors. The idea of an advisory board was also discussed (one that would look at production), and the woman representative on that, Jones said, should be

30 Ibid., para. 19974, 737.

31 Ibid., para. 19965, 736.

32 Ibid., para. 16905, 588.

33 Ibid., para. 16923, 589-60.

34 Marilyn Lake, 'The Independence of Women and the Brotherhood of Man: Debates in the Labour Movement Over Equal Pay and Motherhood Endowment in the 1920s', Labour History 63 (November 1992): 5-6. 
an educated and experience[d] woman, preferably a married woman, who understands the child mind, and would be able to lend valuable assistance in consequence of her experience. Such a person ... should have the necessary educational qualifications and should be one which has sufficient leisure to devote time to the uplifting of the people. ${ }^{35}$

Edith Cowan gave evidence in her capacity as a member of the National Council of Women (she was also a member of the Children's Court in Perth at the time). Cowan stated on the inclusion of women on censorship boards that in 'our opinion, the mothers of children have every right to say something in this matter' ${ }^{36}$

In reading these women reformers' presentations, they are claiming public space for themselves as enfranchised citizens, while simultaneously asserting women's specific skills and expertise as distinct from men, whether they are obtained 'naturally' or professionally. Demanding a place for domestic and maternal knowledge has been aptly described by Ellen Warne as 'civic maternalism'. ${ }^{37}$ As explicitly stated by Edith Waterworth, these women's public mothering was for all children including those belonging to 'women who do not care what happens to their children'. ${ }^{38}$ So whether censoring films or advising film production, the women giving evidence at the royal commission clearly advocated for their representation on almost all proposed boards. It was acknowledged that this was their right as citizens, but significantly it was primarily as guardians of children that claims were made. If we read the questioning of the commissioners as representing the viewpoint of the state, these women's claims were generally intelligible but were interrogated. The women witnesses were required to staunchly defend their position.

Ultimately, the royal commission recommended that a federal board of film censors and a censorship board of appeal be established with three and five members respectively. ${ }^{39}$ Both of these boards were to include one woman. Although the States agreed that uniform legislation was desirable, they were unwilling to surrender their rights for this to be achieved; ${ }^{40}$ consequently, when the new legislation took effect in January 1929, all States except Victoria maintained their right to independent State censorship. ${ }^{41}$ Many recommendations of the royal commission were not immediately realised after they were handed down

\footnotetext{
$35 R C E$, para. $3428,114$.

36 Ibid., para. 14695, 502.

37 Ellen Warne, 'The Mother's Anxious Future: Australian Churchwomen Meet the Modern World, between the 1890s and the 1930s' (PhD thesis, Department of History, University of Melbourne, 2000), 5.

$38 R C E$, para. $16909,588$.

39 Commonwealth of Australia, 'Report of the Royal Commission', paras. 50 (1) and (7), 8.

40 Bertrand, Film Censorship, 79-81.

41 Andrea Allard, 'Grand Gala of Gab (1928-1939)', in Cinema in Australia: A Documentary History, ed. Ina Bertrand (Sydney: UNSW Press, 1989), 127.
} 
because the States had not handed powers over to the Commonwealth. ${ }^{42}$ In mid 1928, the National Council of Women passed a resolution at their monthly general meeting asking the NSW State Government to hand the appropriate powers to the Federal Government to implement the commission's recommendations. ${ }^{43}$ Action on this matter, however, was not swift, which troubled many members of the film industry. ${ }^{44}$

Agreements were finally made and the process of establishing the censorship boards began, with more than 1,000 applications for the positions, and a large number of those came from women. ${ }^{45}$ While we can see these formal positions available for at least two women to exert influence in society, this influence, however, was not universally supported. For instance, the motion picture industry paper Everyones mocked the credentials listed by female applicants to the censorship board, which they reported 'ranged from domestic duties to a sturdy belief in birth-control'. They despaired: 'God help the two men!'46 These credentials, and by association the position of women as the prime public guardians of children, were not seen by Everyones as a valuable contribution to film culture. The notion of women's 'interference' in the film industry was not limited to the censorship board. For example, a WCTU film investigation in Melbourne was reported with the title 'Well, Ladies Must Talk!' and concluded with 'Doesn't it make you tired?' ${ }^{47}$ Everyones, with an air of novelty, did often report favourably on the work of women filmmakers, ${ }^{48}$ but they did not see women's explicit political involvement with the regulation of film as anything other than an undeserved and unwanted intrusion. Women's presence, let alone leadership, was not welcomed. In financial terms, women's work on censorship boards was not remunerated equally with that of men. The salary was $£ 3$ per day for the male censor and £2 per day for the woman board member. ${ }^{49}$ The

\footnotetext{
42 'Control of Films, Conference of States, Wider Powers Sought', Sydney Morning Herald, 12 May 1928: 18. 43 'National Council of Women', Sydney Morning Herald, 1 June 1928: 5. Although, later in the year at the annual meeting of the federal council of the National Councils of Women, there was much debate as to whether States should retain their powers to censor films locally: 'Federal Conference National Councils of Women', Sydney Morning Herald, 19 July 1928: 5; 'Council of Women, Law Anomalies Discussed, Insanity and Divorce', The Argus [Melbourne], 19 July 1928: 14.

44 See, for example: 'Editorial', Everyones, 24 October 1928: 4.

45 'Film Censorship, Many Women Apply, Powers of Appeal Board', Sydney Morning Herald, 31 July 1928: 10; 'Film Censors, 1000 Applications, for Two Positions', Sydney Morning Herald, 14 August 1928: 11; 'Censorship of Films. Many Women Applicants', The Argus [Melbourne], 31 July 1928: 11; 'Film Censorship, Selection of Board Members', The Argus [Melbourne], 5 September 1928: 7.

46 'Women Would A-Censoring Go!', Everyones, 1 August 1928: 5; 'Women Rush Censor Job at £2 a Day', Everyones, 8 August 1928: 35.

47 Pierce Hodgens, 'Well, Ladies Must Talk!', Everyones, 21 November 1928: 40. See also, for example: E. C. Cameron, 'A Woman on the Job', Everyones, 20 November 1929: 22.

48 For example: Juliette de la Ruze, 'Along Film Row', Everyones, 26 September 1928: 5; McDonaghs, 'Concerning the Future', Everyones, 20 June 1928: 5.

49 'Film Censorship, Creating a New Board', The Argus [Melbourne], 30 July 1928: 11.
} 
National Council of Women protested against the pay discrepancy, ${ }^{50}$ but the acting customs minister justified the inconsistency by stating that the male censor would have more duties to perform than the female censor. ${ }^{51}$

\section{Children's access to entertainment}

The other aspect of women's leadership within film culture of the time that I will consider briefly here is the type of entertainment for children that women reformers supported.

The interwar period was a time in which the effects of mass culture on children were fervently debated. The cinema specifically was seen as potentially being able to convince girls to be idle, inebriated and sexual, while boys would desire to be loafers, gamblers and criminals. ${ }^{52}$ The report of the royal commission noted that the 'picture theatre seems to have become part of the life of the child, and therefore every possible precaution should be taken to ensure that the child will derive nothing but good entertainment from the picture screen'. ${ }^{53}$ Women reformers at the royal commission varied as to how valuable they saw film as a medium for providing entertainment. This was applied specifically to children, but also more broadly. Mrs John Jones said, 'I think it must be admitted that pictures provide the cheapest, most enjoyable, and restful form of amusement available; but it is in the interests of the whole community that they should be of a proper standard'.$^{54}$ Mildred Muscio, who was president of the Good Film League, said that films should be used to 'raise the artistic tone of the nation' ${ }^{55}$ Others noted the screen as an important medium of public instruction, ${ }^{56}$ the lure of which 'is so great', said Florence Jones, 'that I am wondering what is going to happen' ${ }^{57}$ In placing the importance of film in the national context, and these women actively working towards improving film culture in society at large, they positioned themselves as (indirectly) working for the state. ${ }^{58}$ Concern was articulated in terms of the effects of film on audiences, in particular for those who were not 'educated and refined'.$^{59}$

\footnotetext{
50 'Film Censorship Board', The Argus [Melbourne], 1 August 1928: 22.

51 'Film Censors, Question of Scale of Fees', The Argus [Melbourne], 8 August 1928: 9.

52 Jan Kociumbas, Australian Childhood: A History (Sydney: Allen \& Unwin, 1997), 191.

53 Commonwealth of Australia, 'Report of the Royal Commission', para. 123, 18.

$54 R C E$, para. 3427, 114.

55 Ibid., para. 21703, 803.

56 Ibid., para. 23999, 919.

57 Ibid., para. 22960, 860 .

58 In discussing women's demands for economic independence through a maternal payment, Lake argues that this repositioned women's duty to the state, rather than to an individual master/husband. While different factors are at play in this case, I would suggest these reformers understood their activism as beneficial to individuals but also to the state. See Lake, 'A Revolution in the Family', 388.

59 Waterworth, in RCE, para. 16951, 590.
} 
In the case of children specifically, there were concerns (although not always consensus) expressed about the impact of films on crime, copycat behaviour, Americanisation of speech, representations of luxury and stories about sex. But throughout these discussions the understanding was always supported that children should be allowed access to entertainment, even if some women thought outdoor activities would be preferable to the dangers of a darkened picture theatre.

Marriage was an institution that some witnesses felt was under threat from films that mocked and made light of the 'marriage tie'. This was deemed particularly dangerous for children and young adolescents. ${ }^{60}$ The fear, as articulated by Edith Waterworth, was that children would believe 'that marriage is not a permanent institution'. ${ }^{61}$ Agnes Knight Goode, who was a member of the State Censor Board in South Australia, ${ }^{62}$ condemned films more broadly for their insidiousness, which would affect 'the rising generation and our young married women' ${ }^{63}$ Goode described a film she and the other SA female censor wanted to reject because 'childbirth was depicted as a very dangerous thing' ${ }^{64}$ In the unnamed film, a young woman refused to marry a man whom she loved because she had seen two women die in childbirth and 'was terrified that this might happen to her' ${ }^{65}$ While the perspective of these two women censors was not the opinion that was followed, it was an avenue through which they could express what they saw as a fundamentally different outlook to their male counterparts and that they sought to provide entertainment that was aligned to their beliefs to young audience members.

What was shown onscreen was understood as important. Rich explicitly placed her understanding of this in a psychological framework. Films could not be easily forgotten as all 'modern psychologists, including Freud, are unanimous that we are the slaves of our childhood, and that the earlier and plastic years of life are the most important for the development of character ${ }^{\prime}{ }^{66}$ While most of the women reformers did not use Freudian or psychological language and analysis, they did refer to notions of children as sexual beings requiring sex education, and Rich explicitly postulated on the internal effects of film entertainment on children (and women). In the evidence Jones gave, she described the impact of screen entertainment: 'We are exploiting our children's love of movement

60 Waterworth, in ibid., para. 16918, 589; Florence Jones, in RCE, para. 22956, 860.

61 Ibid., para. 16918, 589.

62 She was also a justice of the peace and a municipal councillor in Adelaide. RCE, 549.

63 Ibid., para. 15845, 549.

64 Ibid., para. 15903, 551.

65 Despite their concerns, the film was passed for exhibition. Ibid., para. 15903, 551-2.

66 Ibid., para. 19986, 737. 
and colour and the working of their imagination. ${ }^{67}$ The Saturday matinee was of particular concern to Jones, who was convinced that unsuitable films were shown. She described a picture of

a divorce scene, with a woman standing behind a screen taking off her garments, including her undergarments one by one, and throwing them over the screen into a part of the room where her husband and another woman were sitting together. We may think that such things are funny, but I do not believe that our children think they are. We are forming their tastes, and when the children see that their parents are amused at such scenes they are amused also. ${ }^{68}$

For Jones, the presence of parents was not always enough to protect children for, as in the example here, they were the ones teaching their children badly. Guardians were required. Jones said: 'If open-air playgrounds have guardians on Saturday afternoons surely the children in picture theatres should be similarly protected.' Women should carry out this work: 'We cannot expect business men to give up their Saturday afternoons to act as guardians of the children in picture theatres, and therefore this work could very well be carried out by women helpers. ${ }^{69}$ In this scenario, men's access to leisure time should not be interfered with, and women's role here is clearly identified as work - work that assisted children in safely participating in leisure activities.

The final report of the royal commission did not engage with the explicitly gendered nature of access to leisure, but noted when commenting on possible age restrictions to cinema attendance that any regulations prohibiting children from cinemas at night would be deemed 'unjust', and if children were required to be accompanied by adults at night screenings this would 'prove a hardship' ${ }^{70}$ It is not clear who, in fact, experiences the hardship - the children or the parents. Most of the women giving evidence acknowledged that completely excluding children from the cinema would be unfair on young parents, as it would mean they would also be unable to attend the theatre if they could not bring their children. ${ }^{71}$ But strong statements were made in reference to parents, and specifically mothers, who reportedly prioritised their own leisure before the care of their children. Waterworth believed that a 'worse type of woman is the one who leaves her babies at home whilst she goes to a place of entertainment' ${ }^{72}$ Fanny Cocks, the principal of women police in Adelaide, presented evidence in a report from many people including Miss Lee, a probation officer of the State

67 Ibid., para. 3328, 108.

68 Ibid.

69 Ibid.

70 Commonwealth of Australia, 'Report of the Royal Commission', para. 133, 19.

$71 R C E$, para. 21742, 804; also Florence Jones, para. 22970, 860.

72 Ibid., para. 6909, 588. 
Children's Department. Lee reported that often children from very poor homes were the ones whose 'drunk parents' gave them money to go to the cinema. ${ }^{73}$ Mrs Goode conveyed the story that she had

heard of little children being sent to the pictures at night by themselves while their mothers have gone to other entertainments. The women police have found little children sitting on the footpath waiting for their mothers to come home from the pictures. I much prefer to see children at pictures than in the congested streets. ${ }^{74}$

These scenarios illustrate the concern that pictures had caused changes in behaviour that resulted in mothers' neglect of their children. In this way mothers' civic right to leisure was in practice understood as of secondary concern to their role in caring for children.

As can be seen in the evidence given by women reformers interested in film culture, they expressed some alarm about this modern medium of entertainment and, in particular, the influence it had on children and adolescents. The reformers constructed a place for themselves within the public debate in maternalistic terms, although how maternal skills were obtained and respected was contested. In examining these reformers' actions we can see how they continually needed to defend their public interventions, to justify their activism. It was through the concept of civic maternalism that they legitimated their interventions as they sought to influence society and mobilise change in the public agenda. Not only in this case study can we see white women's reform work as establishing leadership positions for themselves; in doing this, they were also strongly involved in facilitating children's social citizenship and access to what these women believed would be better entertainment for children.

\section{References}

Allard, Andréa. 'Grand Gala of Gab (1928-1939).' In Cinema in Australia: A Documentary History, edited by Ina Bertrand, 121-6. Sydney: UNSW Press, 1989.

Bertrand, Ina. Film Censorship in Australia. Brisbane: University of Queensland Press, 1978.

73 Ibid., para. 16049, 558.

74 Ibid., para. 15889, 551. 
Bygott, Ursula. 'Wallace, Sir Robert Strachan(1882-1961).' Australian Dictionary of Biography Online. Canberra: National Centre of Biography, The Australian National University, 1990. http://adb.anu.edu.au/biography/wallace-sirrobert-strachan-8962/text15767.

Cameron, E. C. 'A Woman on the Job.' Everyones, 20 November 1929: 22.

'Censorship of Films. Many Women Applicants.' The Argus [Melbourne], 31 July 1928: 11.

Collins, Diane. 'Cinema and Society in Australia 1920-1939.' PhD thesis, Department of History, University of Sydney, 1975.

Collins, Diane. Hollywood Down Under: Australians at the Movies 1896 to the Present Day. Sydney: Angus \& Robertson, 1987.

Commonwealth of Australia. Royal Commission on the Moving Picture Industry in Australia, Minutes of Evidence. Canberra: Commonwealth of Australia, 1927.

Commonwealth of Australia. 'Report of the Royal Commission on the Moving Picture Industry in Australia.' Commonwealth Parliamentary Papers, Session 1926-27-28, vol. IV, pt 2, 1371-1409.

'Concerning the Future.' Everyones, 20 June 1928: 5.

'Control of Films, Conference of States, Wider Powers Sought.' Sydney Morning Herald, 12 May 1928: 18.

'Council of Women, Law Anomalies Discussed, Insanity and Divorce.' The Argus [Melbourne], 19 July 1928: 14.

de la Ruze, Juliette. 'Along Film Row.' Everyones, 26 September 1928: 5

'Editorial.' Everyones, 24 October 1928: 4.

'Federal Conference National Councils of Women.' Sydney Morning Herald, 19 July 1928: 5 .

'Film Censors, 1000 Applications, for Two Positions.' Sydney Morning Herald, 14 August 1928: 11.

'Film Censors, Question of Scale of Fees.' The Argus [Melbourne], 8 August 1928: 9.

'Film Censorship Board.' The Argus [Melbourne], 1 August 1928: 22.

'Film Censorship, Creating a New Board.' The Argus [Melbourne], 30 July 1928: 11. 
'Film Censorship, Many Women Apply, Powers of Appeal Board.' Sydney Morning Herald, 31 July 1928: 10.

'Film Censorship, Selection of Board Members.' The Argus [Melbourne], 5 September 1928: 7 .

Harvester Case, Ex parte HV McKay, 1907, 4. Canberra: Parliament of Australia, Parliamentary Library. http:/www.aph.gov.au/binaries/library/intguide/ law/harvester.pdf.

Hodgens, Pierce. 'Well, Ladies Must Talk!' Everyones, 21 November 1928: 40.

Kociumbas, Jan. Australian Childhood: A History. Sydney: Allen \& Unwin, 1997.

Lake, Marilyn. 'The Independence of Women and the Brotherhood of Man: Debates in the Labour Movement Over Equal Pay and Motherhood Endowment in the 1920s.' Labour History 63 (November 1992): 1-24.

Lake, Marilyn. 'A Revolution in the Family; the Challenge and Contradictions of Maternal Citizenship in Australia.' In Mothers of a New World: Maternalist Politics and the Origins of Welfare States, edited by Seth Koven and Sonya Michel, 378-95. New York: Routledge, 1993.

Lake, Marilyn. 'Feminist Creating Citizens.' In Creating Australia: Changing Australian History, edited by Wayne Hudson and Geoffrey Bolton, 96-105. Sydney: Allen \& Unwin, 1997.

'National Council of Women.' Sydney Morning Herald, 1 June 1928: 5.

Petrow, Stefan. 'Leading Ladies: Women and Film Censorship in Early Twentieth Century Tasmania.' Tasmanian Historical Research Association Papers and Proceedings 41(2) (June 1994): 74-83.

Pike, Andrew and Ross Cooper. Australian Film. Melbourne: Oxford University Press, 1981.

Schrag, Francis. 'Children and Democracy: Theory and Policy.' Politics, Philosophy \& Economics 3(3) (October 2004): 365-6.

Warne, Ellen. 'The Mother's Anxious Future: Australian Churchwomen Meet the Modern World, between the 1890s and the 1930s.' PhD thesis, Department of History, University of Melbourne, 2000.

‘Women Rush Censor Job at £2 a Day.' Everyones, 8 August 1928: 35.

'Women Would A-Censoring Go!' Everyones, 1 August 1928: 5. 
This text taken from Diversity in Leadership: Australian women, past and present, edited by Joy Damousi, Kim Rubenstein and Mary Tomsic, published 2014 by ANU Press, The Australian National University, Canberra, Australia. 